JPPI Vol 8 No 2 (2018) 141 - 153

Jurnal Penelitian Pos dan Informatika

771/AU1/P2MI-LIPI/08/2017

$32 a / E / K P T / 2017$

e-ISSN: 2476-9266

p-ISSN: 2088-9402

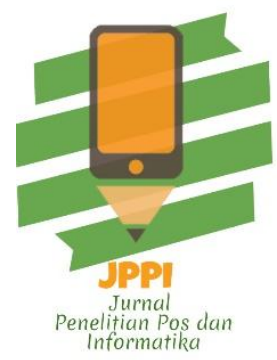

DOI:10.17933/jppi.2018.080205

\title{
ANALISIS KINERJA PEGAWAI PUSBINDIKLAT PENELITI LIPI BERDASARKAN POLA PEMANFAATAN INTERNET MELALUI PENDEKATAN WEB USAGE MINING
}

\section{PERFORMANCE ANALYSIS OF PUSBINDIKLAT PENELITI LIPI EMPLOYEE BASED ON INTERNET USAGE USING WEB USAGE MINING APPROACH}

\author{
Sutrisno Heru Sukoco' ${ }^{1}$, Imas Sukaesih Sitanggang ${ }^{2}$, Heru Sukoco ${ }^{3}$ \\ ${ }^{123}$ Program Studi Magister Ilmu Komputer \\ Departemen Ilmu Komputer FMIPA IPB, Kampus IPB Baranangsiang, Jl. Raya Pajajaran, Bogor 16127 \\ ${ }^{1}$ Pusbindiklat Peneliti LIPI, Jl. Raya Bogor KM 46 Cibinong, Bogor 16911 \\ 'sutrisno.kun@gmail.com
}

Naskah diterima: 1 Agustus 2018; Direvisi : 29 November 2018 ; Disetujui : 12 Desember 2018

\begin{abstract}
Abstrak
Pengukuran kinerja pegawai dalam penggunaan layanan internet dapat dilakukan sebagai bagian dari penilaian kinerja. Pendekatan web usage mining melalui pengamatan rekam jejak akses internet yang tersimpan pada proxy server merupakan salah satu cara yang dapat diterapkan untuk memahami perilaku pengguna. Penelitian ini bertujuan untuk mendapatkan gambaran perilaku pegawai Pusbindiklat Peneliti LIPI dalam memanfaatkan layanan internet, mengukur level produktivitas pegawai berdasarkan lama waktu akses terhadap situs yang tidak mendukung pekerjaan dan memetakan kategori situs yang diakses apakah medukung tugas fungsi jabatannya. Penerapan algoritme clustering KMeans digunakan untuk memudahkan memahami pola akses pengguna. Data yang digunakan adalah log proxy server dan nilai perilaku pegawai Pusbindiklat Peneliti LIPI periode Agustus-Desember 2016. Hasil penelitian menunjukkan pola pemanfaatan internet oleh pegawai Pusbindiklat Peneliti LIPI belum sepenuhnya mendukung tugas fungsi jabatannya. Sekitar $83 \%$ pegawai menggunakan internet untuk mengakses situs yang tidak mendukung pekerjaan berada pada level rendah (0-4 jam per minggu). Berdasarkan hasil tersebut dapat disimpulkan bahwa perilaku penggunaan internet yang dilakukan pegawai Pusbindiklat Peneliti LIPI tidak mempengaruhi produktivitas secara signifikan.
\end{abstract}

Kata kunci: clustering, K-Means, log proxy server, kinerja pegawai, web usage mining

\begin{abstract}
Measurement of employee performance in the use of internet services can be conducted as part of an employee's performance target. Web usage mining approach through observation of internet access records stored in the proxy server can be applied in understanding user behavior. This study aims to obtain an overview of employee behavior in utilizing internet services in Pusbindiklat Peneliti LIPI, measure the level of employee productivity based on the length of time access to sites that do not support the work and map the category of sites accessed to the task duty of an employee. K-Means clustering algorithm is used to group user access patterns. The data used are proxy server logs and employee's performance target in Pusbindiklat Peneliti LIPI in a period of August-December 2016. The results show that the patterns of Internet use by employees Pusbindiklat Peneliti LIPI do not fully support the job function. About $83 \%$ of employees use the internet to access sites do not support jobs at low-level access (ranging from 0-4 hours per week). Based on these results, it can be concluded that the behavior of internet use by employees of Pusbindiklat Peneliti LIPI does not affect their productivity significantly.
\end{abstract}

Keywords: clustering, K-Means, log proxy server, performance of employees, web usage mining 


\section{PENDAHULUAN}

Penggunaan internet di Indonesia berdasarkan data APJII dari tahun ke tahun terus bertumbuh, jumlah pengguna internet pada tahun 2016 sebanyak 132,7 juta bertambah menjadi 143.26 juta di tahun 2017. Berdasarkan hasil survei tahun 2016 jumlah pengguna internet dari lingkungan pekerja atau wiraswasta mencapai 82,2 juta atau sekitar $62 \%$. Gambaran tersebut menunjukkan internet sudah menjadi kebutuhan bagi sebagian besar masyarakat Indonesia. Layanan internet dinilai dapat memberikan dampak positif dalam peningkatan efektifitas dan efisiensi kerja, tetapi pada kenyataannya terkadang ketersediaan layanan internet yang dimiliki oleh instansi pemerintah tidak serta merta memberikan kontribusi yang besar dikarenakan perilaku kerja pegawainya yang belum taat azas dalam pemanfaatannya. Merujuk pada peraturan pemerintah Nomor 46 Tahun 2011 tentang Penilaian Prestasi Kerja Pegawai Negeri Sipil menyebutkan bahwa Prestasi Kerja terdiri atas Sasaran Kinerja Pegawai (SKP) dan Perilaku Kerja. Unsur perilaku kerja memiliki andil yang cukup besar dalam penilaian prestasi kerja pegawai dengan bobot nilai mencapai $40 \%$. Aspek perilaku kerja meliputi orientasi pelayanan, integritas, komitmen, disiplin, kerjasama dan kepemimpinan.

Pengamatan perilaku dalam pemanfaatan internet selama jam kerja merupakan salah satu cara yang dapat dijadikan pertimbangan untuk menilai perilaku kerja pegawai. Lama waktu akses internet dan jenis situs yang sering dikunjungi dapat dijadikan sebagai salah satu tolak ukur penilaian kinerja pegawai (Fathonah \& Hartijasti, 2014). Hasil penelitian yang dilakukan oleh (Yusriani \& K.
Suprapto, 2016) menunjukkan tingkat akses masyarakat pada website pemerintah masih di bawah akses pada media sosial, streaming hal ini sejalan dengan hasil survei yang dilakukan oleh APJII pada tahun 2016 yang menunjukan jenis konten paling banyak diakses adalah media sosial, hiburan dan berita. Jenis konten media sosial yang paling banyak diakses berdasarkan urutan terbanyak diakses pada tahun tersebut adalah Facebook, diikuti oleh Instagram, dan Twitter. Kondisi tersebut menggugah pimpinan untuk meninjau kembali layanan internet yang dimiliki, apakah pemanfaatan layanan internet lebih banyak digunakan untuk mengakses website yang mendukung pekerjaan ataukah tidak mengingat kondisi bandwidth jaringan internet pada tahun 2016 alokasi bandwidth yang disediakan kondisinya kekurangan, hanya 50-60 Mbps. Pola pemanfaatan internet dapat digali melalui rekam jejak penggunaan internet yang tersimpan pada server dalam bentuk log, salah satunya adalah proxy server logs (Zhang, Dai, \& Zhou, 2010). Penerapan sistem proxy server sendiri merupakan salah satu kebijakan yang ditetapkan oleh pengelola jaringan di lingkungan LIPI.

Salah satu aplikasi data mining yang digunakan untuk menemukan pengetahuan yang tersembunyi pada fail log adalah web usage mining (Pamutha, Chimphlee, Kimpan, \& Sanguansat, 2012). Terdapat beberapa algoritme yang mendukung penerapan web usage mining antara lain association rule generation, sequential pattern generation, dan clustering. Algoritme clustering lazim digunakan untuk menggali informasi dari kumpulan data dan mengelompokkannya berdasarkan kemiripan karakteristik (Chitraa \& Thanamani, 2012). 
Penerapan clustering dengan algoritme K-Means diharapkan dapat menggambarkan karakteristik, pola pemanfaatan layanan internet dan produktivitas pegawai (Xu \& Liu, 2010). Beberapa penelitian tentang perilaku pengguna internet pernah dilakukan, antara lain oleh (Zubi, Saleh, \& Raiani, 2014) tentang web mining untuk memahami perilaku pengguna menggunakan web log dataset. Penelitian lain yang dilakukan oleh Roiha, (2017) menunjukkan bahwa kategori blog, online shop dan media sosial merupakan website yang sering dikunjungi oleh pengguna internet di lingkungan pemerintah Kota Surabaya.

Berdasarkan uraian di atas maka perlu dilakukan penelitian lebih lanjut tentang analisis kinerja pegawai Pusbindiklat Peneliti LIPI berdasarkan pola pemanfaatan internet melalui pendekatan web usage mining. Hasil penelitian diharapkan dapat dijadikan sebagai rekomendasi untuk meninjau kembali kebijakan pemanfaatan layanan internet serta sebagai bahan pertimbangan bagi pengambil kebijakan untuk menilai kinerja pegawai terkait pemanfaatan layanan internet yang tersedia apakah sudah sesuai dalam menunjang tugas dan fungsinya.

\section{METODE}

Pada penelitian ini menggunakan data primer berupa berkas log server proxy LIPI periode bulan Agustus-Desember 2016 dan data Sasaran Kinerja Pegawai (SKP) di lingkungan Pusbindiklat Peneliti LIPI tahun 2016. Sumber data yang digunakan hanya berasal dari koneksi internet melalui server proxy, akses internet di luar server proxy tidak termasuk dalam penelitian ini. Data log terkumpul sebanyak 59 access log file dengan ukuran yang bervariasi dari mulai $52 \mathrm{MB}$ sampai dengan $8.9 \mathrm{~GB}$, total access log yang diperoleh sebesar $146 \mathrm{~GB}$ dalam bentuk berkas kompres (.gz).

Penelitian dilaksanakan dalam 2 tahap utama, tahap pertama dimulai dari pemahaman masalah terdiri dari identifikasi dan perumusan masalah untuk mendapatkan data dan informasi mengenai hal yang terkait dengan web usage mining, antara lain sumber data $\log$, profil pegawai, akun internet (username), tahapan dilanjutkan dengan pengumpulan data. Metode yang digunakan untuk pengumpulan data dilakukan dengan cara copy rekam jejak akses internet yang tersimpan dalam server proxy selama 6 bulan terakhir tahun 2016. Selanjutnya, penggunaan data profil pegawai dan akun internet sudah disesuaikan dengan Peraturan Menteri Komunikasi dan Informatika Nomor 20 Tahun 2016 tentang Perlindungan Data Pribadi dalam Sistem Elektronik, salah satu caranya adalah dengan tidak menyebutkan nama individu secara langsung tetapi hanya menuliskan jabatannya saja guna kepentingan penelitian. Tahap kedua merupakan tahap web usage mining, meliputi praproses, pattern discovery dan pattern analysis, diakhiri perumusan kesimpulan tentang analisis pola pemanfaatan layanan internet dibandingkan dengan kinerja atau produktivitas pegawai. Detail tahapan penelitian ditunjukkan pada Gambar 1. 


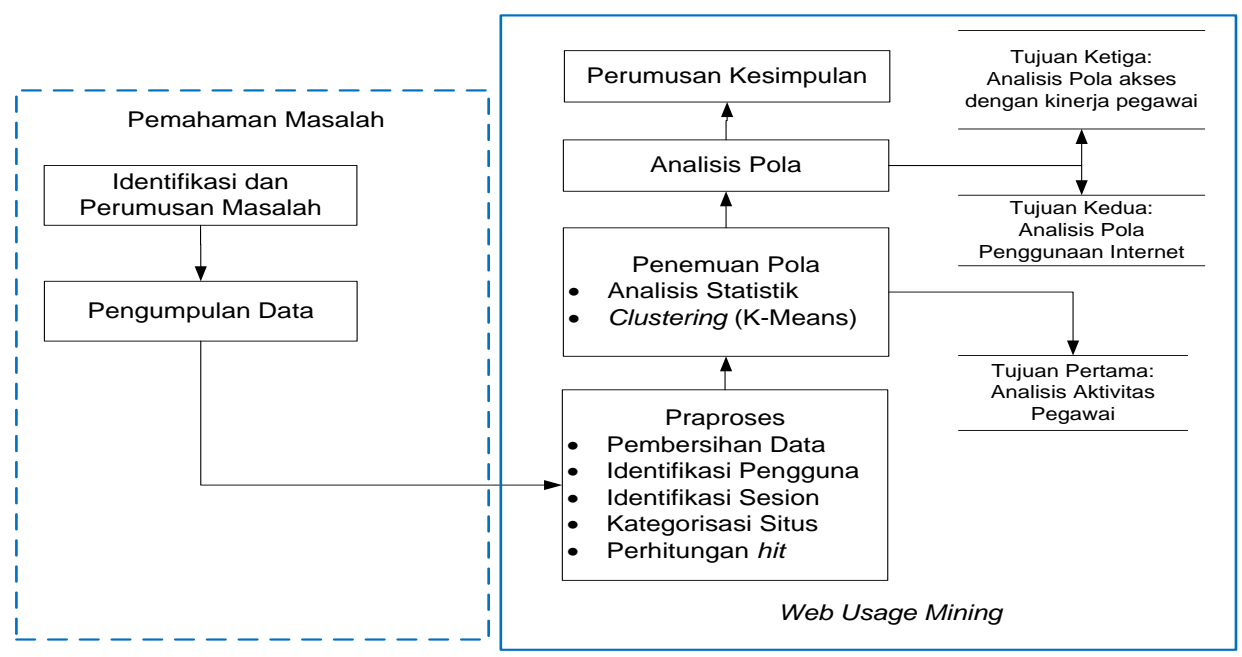

Gambar 1. Tahapan penelitian

Praproses merupakan tahapan awal dalam web usage mining ditujukan untuk mengubah data mentah ke dalam satu set profil pengguna dengan melakukan standardisasi data dan menghilangkan bagian data tertentu yang tidak diperlukan dalam proses mining (Dong, 2009). Tahapan praproses meliputi pembersihan data untuk menghilangkan data yang tidak relevan, noisy dan entri data yang tidak dibutuhkan.. Setelah menghapus baris $\log$ yang tidak relevan, tahapan selanjutnya adalah memilih field yang dibutuhkan. Field yang dibutuhkan antara lain field time yang merupakan waktu pengaksesan, username pengguna, dan URL dari situs yang dikunjungi pengguna. Proses dilanjutkan dengan identifikasi pengguna berdasarkan username, tahap berikutnya identifikasi session untuk mengidentifikasi aktivitas transaksi berdasarkan selang waktu untuk menghasilkan kualitas temuan pola. Kategorisasi situs ditujukan untuk mendefinisikan situs berdasarkan jenis kategori yang telah ditetapkan. Perhitungan hit dilakukan untuk menghitung berapa kali sebuah situs dikunjungi. Tahap kedua pattern discovery meliputi analisis statistik dan proses clustering dengan algoritme K-Means. Tahap ketiga pattern analysis, dilakukan analisis untuk menilai produktivitas atau kinerja pegawai Pusbindiklat Peneliti LIPI.

\section{HASIL DAN PEMBAHASAN}

\section{Praproses Data}

Tahap pra-proses mencakup pembersihan data, identifikasi pengguna, user session identification, kategorisasi situs, perhitungan hit dan perhitungan waktu pemakaian. Tahap praproses cenderung memakan waktu cukup lama terutama diproses kategorisasi, hal ini dikarenakan banyak domain dengan ekstensi .com, co.id, .org, .web.id, dan .net yang memanfaatkan domain tersebut sebagai situs pribadi, jurnal dan lainnya

\section{Pembersihan data}

Pembersihan data dilakukan pada baris record yang berisi gambar, script pendukung, format informasi (iklan), record dengan kode status HTTP yang gagal serta metode akses selain GET dan POST (Kerkhofs, Vanhoof, \& Pannemans, 2001). Sejumlah record yang tidak sepenuhnya dilakukan oleh pengguna secara langsung seperti update 
sistem operasi atau antivirus termasuk record yang dihapus (Weinreich, Obendorf, \& Herder, 2006). Pembersihan baris log yang berisi record yang dihasilkan oleh mesin pencari otomatis, seperti Crawler, Spider, dan Robot serta cookies (Nithya \& Sumathi, 2012). Proses tersebut mengurangi jumlah baris record sebanyak 29,313,156, jumlah record akhir yang tersisa sebanyak 30,406,348 record. Field record yang diambil dari tahap pembersihan data adalah IP Address pengguna, username pengguna, URL atau alamat situs yang dikunjungi dan waktu akses (Tanggal, Jam dan Detik).

\section{Identifikasi Pengguna}

Identifikasi pengguna didasarkan pada username. Baris record dengan username yang berisi tanda ““, menggunakan entri data username sebelumnya atau melihat kumpulan baris record yang sama (Chitraa \& Davamani, 2010); (Lüderitz, 2006). Identifikasi pengguna yang dihasilkan sebanyak 9.422 IP address yang berbeda dan 3.092 username. Pengguna tersebar pada beberapa satuan kerja (satker) yang tersebar dibeberapa wilayah di Indonesia, setiap satuan kerja memiliki segmen $I P$ address yang berbeda. Identifikasi lokasi pengguna bisa menggunakan lokasi jaringan yang terpasang atau asal satker. Identifikasi jabatan pengguna bisa diperoleh melalui penelusuran username yang didapatkan.

\section{Kategorisasi Situs}

Kategorisasi situs ditujukan untuk membantu memudahkan manajemen data (Cadez, Heckerman, Meek, Smyth, \& White, 2003). Proses kategorisasi situs dilakukan dengan mengindentifikasi top level domain seperti "go.id/ac.id" dan kata kunci tertentu seperti blogspot. Rujukan lain untuk kategori situs menggunakan referensi Trustedsource Web Database (Mcafee) dan Palo Alto Networks URL filtering. Sebanyak 104 kategori didefinisikan oleh Mcafee, dalam penelitian ini kategori situs dikelompokkan dalam 22 kategori agar klasifikasi lebih fokus. Untuk memudahkan proses, kategori situs didefinisikan dengan memberikan kode kategori seperti ditunjukkan pada Tabel 1.

\section{Perhitungan hit}

Perhitungan hit dilakukan dengan menghitung berapa kali sebuah situs dikunjungi oleh pengguna. Penjumlahan hit dilakukan untuk setiap username pegawai. Setelah tahapan praproses selesai diperoleh data berisi jumlah hit untuk masingmasing kategori situs berdasarkan lokasi (lokasi jaringan yang terpasang), kedeputian dan satuan kerja pegawai.

Tabel 1. Kategori situs dan jumlah hitnya

\begin{tabular}{clrrlr}
\hline $\begin{array}{c}\text { Kode } \\
\text { Kategori }\end{array}$ & \multicolumn{1}{c}{ Kategori } & Jumlah hit & $\begin{array}{c}\text { Kode } \\
\text { Kategori }\end{array}$ & Kategori & Jumlah hit \\
\hline k1 & Blogs/wiki & $1,711,502$ & $\mathrm{k} 12$ & News & $5,454,271$ \\
k2 & Business & 856,119 & $\mathrm{k} 13$ & $\begin{array}{l}\text { Online shopping } \\
\text { Organization and }\end{array}$ & $1,720,820$ \\
k3 & Education/references & $1,256,958$ & $\mathrm{k} 14$ & company & 521,244 \\
k4 & Entertainment & $2,176,330$ & $\mathrm{k} 15$ & Pornography & $1,240,496$ \\
k5 & File Sharing & $2,974,468$ & $\mathrm{k} 16$ & Publication & $1,093,571$ \\
k6 & Finance/Banking & 68,167 & $\mathrm{k} 17$ & Real estate & 98,982 \\
k7 & Gambling & 8 & $\mathrm{k} 18$ & Religion & 265,629 \\
k8 & Games & 184,309 & $\mathrm{k} 19$ & Services & $2,383,591$ \\
k9 & Government/military & $3,794,102$ & $\mathrm{k} 20$ & Social Network/Forum & 628,886 \\
\hline
\end{tabular}




\begin{tabular}{|c|c|c|c|c|c|}
\hline k10 & Hacking & 3,439 & k21 & Travel & 325,717 \\
\hline k11 & $I C T$ & 726,264 & $\mathrm{k} 22$ & Uncategory & $2,920,260$ \\
\hline
\end{tabular}

Penemuan Pola

Aktivitas pegawai berdasarkan lokasi kampus

Jumlah hit terbanyak berdasarkan lokasi kampus seperti ditunjukkan pada Tabel 2 berada pada Kampus Cibinong, Jakarta, Bandung, dan Serpong. Kondisi tersebut dianggap wajar karena pada kampus tersebut terdiri dari beberapa satker dengan jumlah pegawai yang cukup banyak. Jumlah hit yang menarik dan menjadi perhatian adalah Kampus Cibinong dengan jumlah satker dan jumlah pengguna kurang dari jumlah pengguna Kampus
Jakarta tetapi jumlah hit terpaut 78,073 hit, jenis kategori yang mendominasi pada Kampus Cibinong adalah government (k9) sedangkan pada Kampus Jakarta adalah news (k12). Kampus lain yang menarik perhatian adalah Kampus Sukabumi, dengan jumlah satker hanya 1 satker dan pengguna 15 orang tetapi jumlah hit mencapai 990,856. Kategori situs yang paling banyak diakses di Kampus Sukabumi adalah kategori file sharing (k5) dan entertainment (k4).

Tabel 2. Jumlah hit berdasarkan lokasi Kampus

\begin{tabular}{lccclccc}
\hline \multicolumn{1}{c}{ Lokasi } & $\begin{array}{c}\text { Jumlah } \\
\text { Hit }\end{array}$ & $\begin{array}{c}\text { Jumlah } \\
\text { Pengguna }\end{array}$ & $\begin{array}{c}\text { Jumlah } \\
\text { Satker }\end{array}$ & Lokasi & $\begin{array}{c}\text { Jumlah } \\
\text { Hit }\end{array}$ & $\begin{array}{c}\text { Jumlah } \\
\text { Pengguna }\end{array}$ & $\begin{array}{c}\text { Jumlah } \\
\text { Satker }\end{array}$ \\
\hline Cibinong & $6,662,258$ & 434 & 7 & Kebumen & 438,696 & 46 & 1 \\
Jakarta & $6,584,185$ & 1027 & 17 & Purwodadi & 370,063 & 85 & 1 \\
Bandung & $5,675,425$ & 632 & 8 & Tual & 285,848 & 13 & 1 \\
Serpong & $5,590,972$ & 614 & 5 & Ambon & 265,757 & 77 & 1 \\
Bogor & 991,234 & 352 & 2 & Lampung & 262,606 & 55 & 2 \\
Sukabumi & 990,856 & 15 & 1 & Yogyakarta & 215,105 & 57 & 1 \\
Cianjur & 676,528 & 73 & 1 & Mataram & 194,599 & 29 & 1 \\
Subang & 652,693 & 104 & 1 & Bitung & 62,693 & 21 & 1 \\
Bali & 450,816 & 79 & 1 & Biak & 34,799 & 12 & 1 \\
\hline Sul
\end{tabular}

Sumber: data hasil pengolahan, lokasi Kampus berdasarkan lokasi jaringan yang terpasang

Aktivitas penggunaan internet berdasarkan sekitar $43 \%$ sedangkan rataan jumlah hit fungsional

\section{kelompok jabatan}

Pola pemanfaatan internet berdasarkan kelompok jabatan didominasi oleh pengguna fungsional umum dan fungsional peneliti, seperti ditunjukkan pada Gambar 2. Rataan jumlah hit yang dihasilkan oleh pengguna fungsional umum sebanyak 600,821 atau peneliti sebanyak $32 \%$. Jenis situs yang paling banyak dikunjungi oleh fungsional umum adalah kategori government (k9) dan file sharing (k5), sedangkan jenis situs yang paling banyak dikunjungi oleh fungsional peneliti adalah kategori news (k12) dan services (k19). 


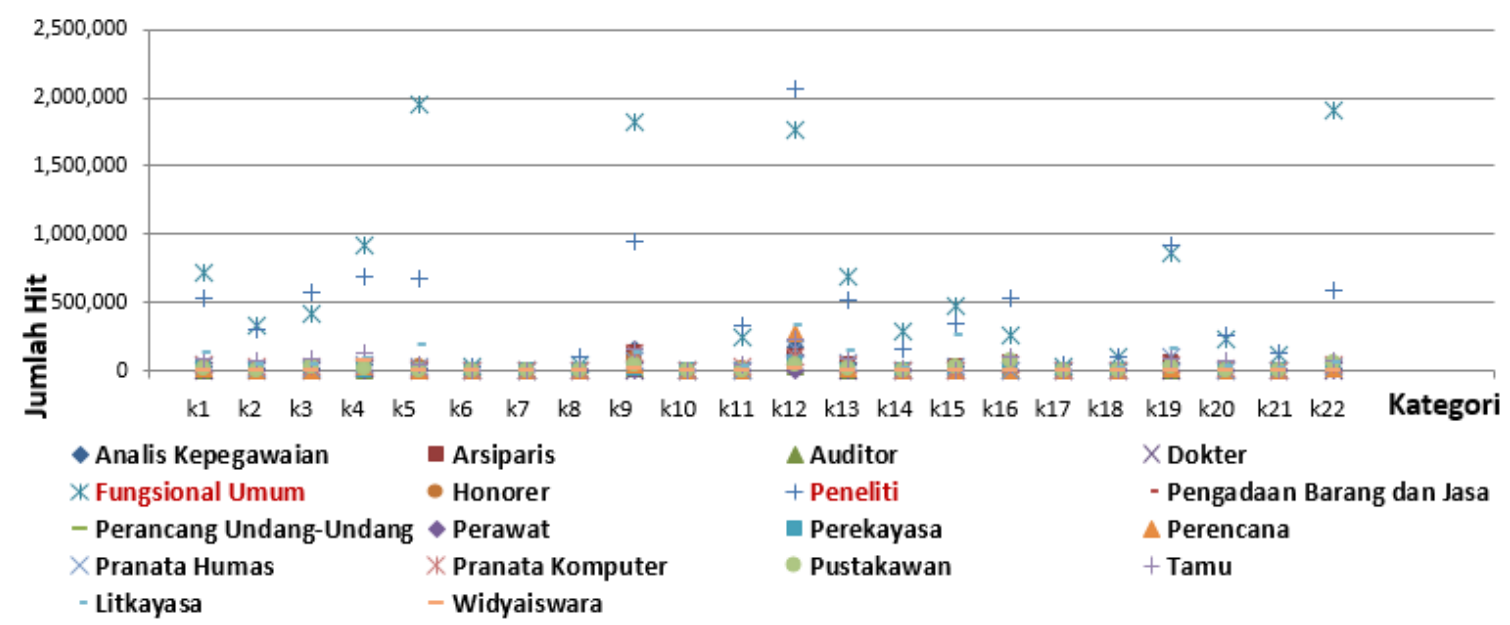

Gambar 2. Jumlah hit berdasarkan jabatan fungsional di lingkungan LIPI Sumber: hasil pengolahan

Tabel 3. Jumlah pegawai berdasarkan kelompok jabatan

\begin{tabular}{|c|c|c|c|c|c|c|c|}
\hline No & Jabatan Pengguna & Jumlah & hit & No & Jabatan Pengguna & Jumlah & hit \\
\hline 1 & $\begin{array}{l}\text { Analis Kepegawaian } \\
\text { (Anpeg) }\end{array}$ & 5 & 26,306 & 6 & $\begin{array}{l}\text { Pranata Komputer } \\
\text { (Prakom) }\end{array}$ & 1 & 22,904 \\
\hline 2 & Peneliti & 1 & 2,481 & 7 & Widyaiswara (WI) & 10 & 116,573 \\
\hline 3 & $\begin{array}{l}\text { Fungsional Umum (F. } \\
\text { Umum) }\end{array}$ & 19 & 268,952 & 8 & Honorer & 1 & 6,499 \\
\hline 4 & Perencana & 5 & 8,363 & 9 & Tamu & 3 & 73,713 \\
\hline 5 & Pranata Humas (Prahum) & 7 & 30,285 & & Total & 52 & 556,076 \\
\hline
\end{tabular}

Sumber: hasil pengolahan

Cluster penggunaan internet di Pusbindiklat Peneliti LIPI

Berdasarkan data rekam akses fail log, jumlah pengguna yang memanfaatkan akses internet di lingkungan Pusbindiklat Peneliti LIPI periode Agustus sampai Desember 2016 sebanyak 52 pengguna. Jumlah pengguna paling banyak memanfaatkan layanan internet berdasarkan kelompok jabatan adalah fungsional umum yang mencapai $48 \%$ dan widyaiswara yang mencapai 21\%, seperti ditunjukan pada Tabel 3.

Karakteristik pengguna internet berdasarkan kelompok jabatan di lingkungan Pusbindiklat dapat dikelompokkan ke dalam dua atau lebih cluster. Penentuan jumlah cluster optimal dengan kondisi data (jumlah baris yang minim) memungkinkan dilakukan dengan menggunakan metode gap statistik. Kriteria cluster optimal ditentukan berdasarkan nilai gap statistik (k) yang paling tinggi, atau yang pertama kali mengindikasi kenaikan gap minimum jika gap selalu naik. Gambar 3 menunjukkan grafik hasil gap statistik semakin meningkat hingga mencapai jumlah klaster maksimal. Pilihan yang ideal untuk kondisi tersebut adalah $\mathrm{k}=3$ karena nilai tersebut merupakan titik yang pertama kali menunjukkan perbedaan gap minimum.

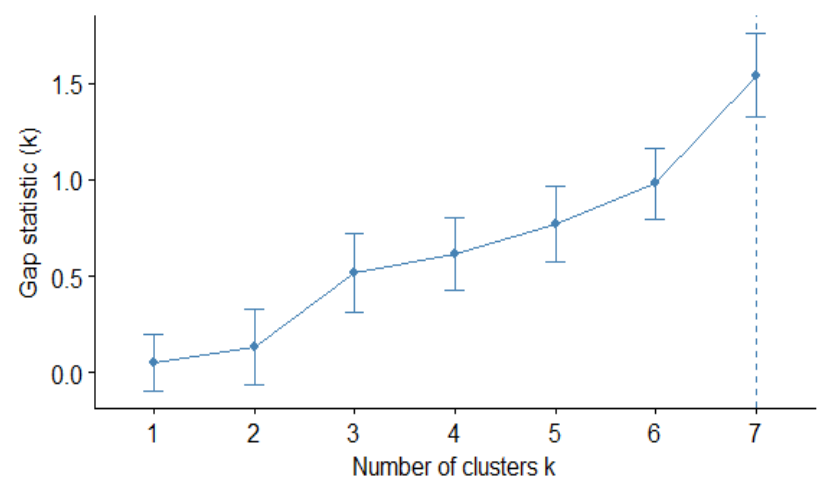


Gambar 3. Nilai k optimal dengan gap statistik

Tabel 4. karateristik cluster berdasarkan kelompok jabatan

\begin{tabular}{|c|c|c|c|c|}
\hline Cluster & Rendah & Sedang & Tinggi & Anggota \\
\hline 1 & $\mathrm{k} 10, \mathrm{k} 18$ & $\begin{array}{c}\mathrm{k} 1, \mathrm{k} 2, \mathrm{k} 3, \mathrm{k} 5, \mathrm{k} 6, \mathrm{k} 8, \\
\mathrm{k} 9, \mathrm{k} 11, \mathrm{k} 12, \mathrm{k} 13, \\
\mathrm{k} 14, \mathrm{k} 15, \mathrm{k} 16, \mathrm{k} 17, \\
\mathrm{k} 19, \mathrm{k} 20, \mathrm{k} 21, \mathrm{k} 22\end{array}$ & k4 & Widyaiswara \\
\hline 2 & $\begin{array}{c}\mathrm{k} 1, \mathrm{k} 2, \mathrm{k} 3, \mathrm{k} 4, \mathrm{k} 5, \\
\mathrm{k} 6, \mathrm{k} 8, \mathrm{k} 9, \mathrm{k} 11, \mathrm{k} 12, \\
\mathrm{k} 13, \mathrm{k} 14, \mathrm{k} 15, \mathrm{k} 16, \\
\mathrm{k} 17, \mathrm{k} 19, \mathrm{k} 20, \mathrm{k} 21, \\
\mathrm{k} 22\end{array}$ & (1) & 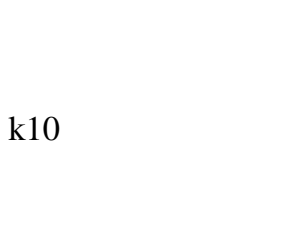 & $\begin{array}{l}\text { Peneliti } \\
\text { Perencana } \\
\text { Pranata Humas } \\
\text { Pranata Komputer } \\
\text { Honorer } \\
\text { Tamu }\end{array}$ \\
\hline 3 & & $\mathrm{k} 10$ & $\begin{array}{c}\mathrm{k} 1, \mathrm{k} 2, \mathrm{k} 3, \mathrm{k} 4, \mathrm{k} 5, \\
\mathrm{k} 6, \mathrm{k} 8, \mathrm{k} 9, \mathrm{k} 11, \mathrm{k} 12, \\
\mathrm{k} 13, \mathrm{k} 14, \mathrm{k} 15, \mathrm{k} 16, \\
\mathrm{k} 17, \mathrm{k} 18, \mathrm{k} 19, \mathrm{k} 20, \\
\mathrm{k} 21, \mathrm{k} 22\end{array}$ & Fungsional umum \\
\hline
\end{tabular}

Setelah penentuan titik optimal dilakukan, proses dilanjutkan penerapan clustering dengan algoritme K-Means. Hasil clustering K-Means ditunjukkan pada Tabel 4. Akses internet dengan jumlah hit tinggi pada hampir seluruh kategori berada pada cluster 3 dengan anggota Fungsional Umum.

Produktivitas dan kinerja pegawai Pusbindiklat Peneliti LIPI berdasarkan perilaku dan pola penggunaan layanan internet

Merujuk penelitian (Fathonah \& Hartijasti, 2014), pengukuran produktivitas kerja pegawai diukur melalui level penggunaan akses internet terhadap situs yang tidak mendukung pekerjaan. (Coker, 2011) menemukan bahwa seorang karyawan yang melakukan akses internet terhadap situs yang tidak mendukung pekerjaan yang berlebihan (lebih dari $12 \%$ dari total jam kerja) akan mengalami penurunan produktivitas kerja. Berdasarkan rujukan tersebut, pengamatan awal untuk menilai produktivitas dilakukan dengan melihat frekuensi akses pegawai selama periode bulan Agustus sampai Desember 2016. Profil frekuensi akses dapat dikelompokkan dalam beberapa cluster. Dengan kondisi data yang memadai, penentuan jumlah optimal cluster dapat dilakukan dengan memanfaatkan 3 metode. Metode pertama menggunakan nilai total wss (whitin sum square) atau dikenal dengan istilah metode elbow, metode kedua sebagai pembanding menggunakan metode silhouette, untuk menduga kualitas dari cluster yang terbentuk, semakin tinggi nilai rata-ratanya maka akan semakin baik, metode ketiga adalah gap statistik. Hasil penentuan nilai $\mathrm{k}$ optimal dengan menggunakan pendekatan ketiga metode tersebut dapat dilihat pada Gambar 4, nilai k=3 merupakan angka optimal untuk membentuk cluster. 


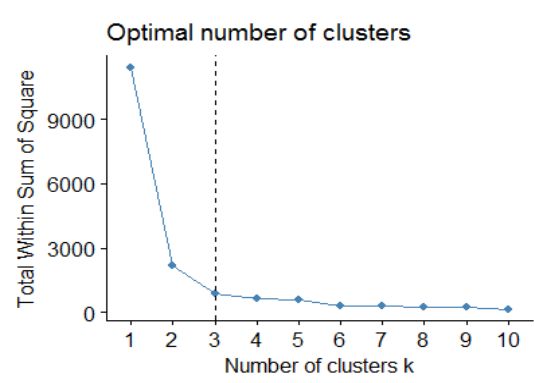

metode elbow

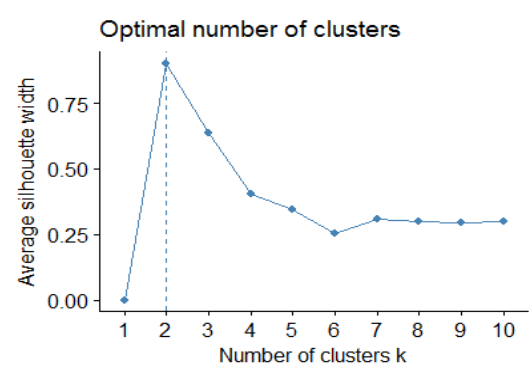

metode Silhoette

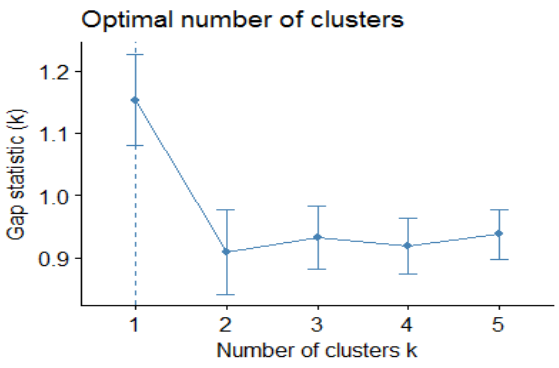

metode Gap Statistic

Gambar 4. Nilai k optimal dengan 3 metode

Tabel 5. Frekuensi akses internet pegawai Pusbindiklat

\begin{tabular}{clcc}
\hline Cluster & \multicolumn{1}{c}{ Level } & Jumlah & Persentase \\
\hline 1 & Rendah (<10 hari dalam 5 bulan) & 4 & $8 \%$ \\
2 & Sedang (10-66 hari dalam 5 bulan) & 17 & $35 \%$ \\
3 & Tinggi (> 66 hari dalam 5 bulan) & 28 & $57 \%$ \\
\hline
\end{tabular}

Sumber: hasil pengolahan

Tabel 6. Waktu akses situs yang tidak mendukung pekerjaan selama jam kerja

\begin{tabular}{clcc}
\hline Cluster & \multicolumn{1}{c}{ Kategori } & Jumlah & Persentase \\
\hline 1 & $\begin{array}{l}\text { Rendah, akses situs yang tidak mendukung di tempat kerja } \\
(0-4 \text { jam perminggu })\end{array}$ & 41 & $84 \%$ \\
2 & $\begin{array}{l}\text { Sedang, akses situs yang tidak mendukung di tempat kerja } \\
(>4-10 \text { jam perminggu })\end{array}$ & 7 & $2 \%$ \\
3 & $\begin{array}{l}\text { Tinggi, akses situs yang tidak mendukung di tempat kerja } \\
(>10 \text { jam perminggu })\end{array}$ & 1 & $2014)$
\end{tabular}

Hasil clustering K-Means dan agregat frekuensi mendukung pekerjaan selama jam kerja tergambar akses pegawai ditunjukkan pada Tabel 5. Presentase pada Tabel 6.

frekuensi akses internet dalam 5 bulan terakhir sebagian besar berada pada level tinggi (cluster 3) dengan rata-rata frekuensi akses 79 hari dari 105 hari kerja.

Tahap selanjutnya adalah pengamatan terhadap lama waktu akses internet pada kategori situs yang tidak mendukung pekerjaan selama jam kerja. Klasifikasi kategori situs yang dianggap kurang mendukung pekerjaan merujuk pada penelitian (Kim \& Byrne, 2011). Hasil clustering menggunakan K-Means dengan nilai optimal $\mathrm{k}=3$ membentuk 3 cluster. Profil dan karakteristik cluster pegawai yang memanfaatkan layanan internet untuk mengakses situs yang tidak

Tabel 6 menunjukkan produktivitas pegawai diukur berdasarkan lama waktu akses penggunaan internet masih dalam ranah produktif, karena $84 \%$ pegawai berada pada cluster 1 yang menandakan bahwa umumnya pegawai mengakses situs yang tidak mendukung pekerjaan rata-rata di bawah 4 jam/minggu. Tetapi terdapat satu pengguna yang berada pada cluster 3 dengan rata-rata waktu akses mencapai $40 \mathrm{jam} / \mathrm{minggu}$.

Setelah mendapatkan gambaran frekuensi akses dan lama waktu akses internet selama jam kerja, tahap selanjutnya dilakukan identifikasi kategori situs yang paling banyak di akses oleh pegawai. Nilai $\mathrm{k}=4$ adalah nilai optimal untuk membentuk cluster 
kategori situs yang paling banyak diakses oleh pegawai. Hasil analisis clustering dengan K-Means menunjukkan $94 \%$ pegawai berada di cluster 2 seperti ditunjukkan pada Tabel 7.

Tahap akhir dilakukan pemetaan kesesuaian perilaku kerja pegawai dengan pola penggunaan internet yang dilakukannya. Pemetaan dilakukan dengan cara membandingkan jenis kategori situs yang diakses pegawai (Tabel 7) dengan kategori situs yang mendukung pekerjaan berdasarkan tugas dan fungsi jabatannya (Tabel 8).
Hasil pemetaan menunjukkan bahwa pegawai belum sepenuhnya menggunakan internet sesuai dengan tugas dan fungsi jabatannya, seperti terlihat pada Tabel 7 sebanyak 94\% pegawai berada pada cluster 2, jenis kategori situs pada cluster tersebut meliputi business (k2), finance/banking (k6), government (k9), hacking (k10), social network (k20), travel (k21), uncategory (k22).

Tabel 7 Cluster kategori situs yang paling banyak diakses oleh pegawai

\begin{tabular}{|c|c|c|c|c|c|}
\hline Cluster & Rendah & Sedang & Tinggi & Sangat tinggi & Jumlah pegawai \\
\hline 1 & $\begin{array}{c}\mathrm{k} 1, \mathrm{k} 2, \mathrm{k} 3, \mathrm{k} 4, \\
\mathrm{k} 6, \mathrm{k} 8, \mathrm{k} 10, \mathrm{k} 11, \\
\mathrm{k} 16, \mathrm{k} 18, \mathrm{k} 21\end{array}$ & $\begin{array}{l}\text { k9, k15, k17, } \\
\text { k20, k22 }\end{array}$ & $\mathrm{k} 5, \mathrm{k} 12, \mathrm{k} 14, \mathrm{k} 19$ & k13 & 1 F. Umum \\
\hline 2 & $\mathrm{k} 13, \mathrm{k} 17, \mathrm{k} 19$ & $\begin{array}{c}\mathrm{k} 1, \mathrm{k} 3, \mathrm{k} 4, \mathrm{k} 5 \\
\mathrm{k} 8, \mathrm{k} 11, \mathrm{k} 12, \\
\mathrm{k} 14, \mathrm{k} 15, \mathrm{k} 16 \\
\mathrm{k} 18\end{array}$ & $\begin{array}{c}\mathrm{k} 2, \mathrm{k} 6, \mathrm{k} 9, \mathrm{k} 10 \\
\mathrm{k} 20, \mathrm{k} 21, \mathrm{k} 22\end{array}$ & & $\begin{array}{l}1 \text { Peneliti } \\
5 \text { Anpeg } \\
17 \text { F. Umum } \\
5 \text { Perencana } \\
7 \text { Prahum } \\
1 \text { Prakom } \\
9 \text { widyaiswara } \\
1 \text { Honorer }\end{array}$ \\
\hline 3 & $\begin{array}{c}\mathrm{k} 5, \mathrm{k} 9, \mathrm{k} 10, \mathrm{k} 12, \\
\mathrm{k} 20, \mathrm{k} 22\end{array}$ & $\begin{array}{c}\mathrm{k} 2, \mathrm{k} 6, \mathrm{k} 8, \mathrm{k} 13, \\
\mathrm{k} 14, \mathrm{k} 15, \mathrm{k} 18 \\
\mathrm{k} 19, \mathrm{k} 21\end{array}$ & $\begin{array}{c}\mathrm{k} 1, \mathrm{k} 3, \mathrm{k} 11, \mathrm{k} 16, \\
\mathrm{k} 17\end{array}$ & k4 & 1 widyaiswara \\
\hline 4 & & & $\mathrm{k} 4, \mathrm{k} 10, \mathrm{k} 17$ & $\begin{array}{c}\mathrm{k} 1, \mathrm{k} 2, \mathrm{k} 3, \mathrm{k} 5, \mathrm{k} 6, \\
\mathrm{k} 8, \mathrm{k} 9, \mathrm{k} 11, \mathrm{k} 12, \\
\mathrm{k} 13, \mathrm{k} 14, \mathrm{k} 15, \\
\mathrm{k} 16, \mathrm{k} 18, \mathrm{k} 19, \\
\mathrm{k} 20, \mathrm{k} 21, \mathrm{k} 22\end{array}$ & $1 \mathrm{~F}$. Umum \\
\hline
\end{tabular}

Keterangan kode kategori (k1 sampai k22) dapat dilihat pada Tabel 1, Sumber: hasil pengolahan data

Tabel 8 Kategori situs berdasarkan tugas dan fungsi jabatan

\begin{tabular}{|c|c|c|}
\hline \multirow[t]{2}{*}{ Jabatan } & \multicolumn{2}{|c|}{ Kategori Situs mendukung pekerjaan } \\
\hline & Utama & Penunjang \\
\hline Analis Kepegawaian & government & education, publication, organization \\
\hline Perencana & government, education & publication, organization, banking, news \\
\hline Pranata Humas & government, news & education, publication, organization \\
\hline Pranata Komputer & ict, education & government, publication, organization, services \\
\hline Fungsional Umum & government & education, government, organization, publication \\
\hline Widyaiswara & education, publication & government, organization, news \\
\hline Peneliti & publication, education & government, organization, news \\
\hline Analis Kepegawaian & government & education, publication, organization \\
\hline
\end{tabular}

Terdapat hasil pemetaan berupa pencilan yang pengguna fungsional umum berada pada kategori menarik perhatian, salah satunya yaitu satu cluster 1. Kondisi tersebut terjadi karena terdapat 
akses yang tinggi pada kategori situs online shopping (k13). Kondisi lainnya, terdapat pengguna fungsional umum berada pada cluster 4. Kondisi tersebut terjadi karena akun salah satu pegawai fungsional umum digunakan oleh beberapa pegawai lainnya. Berikutnya, satu pengguna yang berasal dari jabatan widyaiswara berada pada cluster 3 . Kondisi tersebut terjadi karena terdapat jumlah hit yang tinggi pada kategori entertainment $(\mathrm{k} 4)$.

\section{PENUTUP}

Hasil penelitian menunjukkan bahwa proses web usage mining dapat diterapkan untuk menganalisis kinerja pegawai di lingkungan Pusbindiklat Peneliti LIPI. Nilai k optimal untuk membentuk cluster adalah $\mathrm{k}=3$ dan $\mathrm{k}=4$. Hasil clustering dengan $\mathrm{K}$ Means menunjukkan aktivitas penggunaan internet dilihat dari frekuensi akses sebagian besar pegawai atau sekitar $57 \%$ berada pada level tinggi dengan lama waktu akses internet pada situs yang kurang mendukung pekerjaan umumnya berada pada level rendah atau rata-rata di bawah 4 jam/minggu. Jenis kategori situs yang diakses belum sepenuhnya mendukung pekerjaan. Hasil pemetaan perilaku kerja pegawai dengan pola penggunaan internet masih belum sepenuhnya mendukung tugas dan fungsi jabatannya. Gambaran pola pemanfaatan internet yang dihasilkan dapat dijadikan sebagai salah satu komponen penilaian atau pertimbangan prestasi kerja pegawai oleh pemegang kebijakan. Beberapa saran kebijakan yang dapat diambil antara lain pembatasan akses terhadap kategori situs seperti social network, entertainment, dan file sharing, selanjutnya menghimbau pegawai untuk tidak mengakses situs yang tidak mendukung pekerjaan selama jam kerja. Penataan penggunaan akun perlu diterapkan, agar pola pemanfaatan internet sebagai salah satu tolak ukur penilaian kinerja dapat lebih terukur.

Selanjutnya perlu dilakukan penelitian lebih lanjut untuk meningkatkan akurasi hitungan waktu atau jam pemakaian internet dengan memperhitungkan waktu penggunaan internet oleh pegawai yang memanfaatkan paket data atau akses internet di luar proxy. Selanjutnya untuk menanggulangi tahapan praproses yang terlalu lama perlu dikombinasikan dengan tokenisasi supaya praproses dapat dilakukan lebih cepat. Data penelitian disarankan menggunakan dataset terbaru sehingga monitoring produktivitas kerja pegawai dapat dilakukan secara berkesinambungan. Kategorisasi situs disarankan dikombinasi dengan tokenisasi supaya praproses dapat dilakukan lebih cepat.

\section{UCAPAN TERIMA KASIH}

Ucapan terima kasih disampaikan kepada Lembaga Ilmu Pengetahuan Indonesia dan Pusbindiklat Peneliti LIPI yang telah menyediakan data serta pihak-pihak yang membantu untuk menyelesaikan penelitian ini.

\section{DAFTAR PUSTAKA}

Cadez, I., Heckerman, D., Meek, C., Smyth, P., \& White, S. (2003). Model-Based Clustering and Visualization of Navigation Patterns on aWeb Site. Data Mining and Knowledge Discovery, 7, 399-424.

Chitraa, V., \& Davamani, A. S. (2010). A Survei on Preprocessing Methods for Web Usage Data. International Journal of Computer Science and Information Security, 7(3), 78-83. https://doi.org/10.2200/S00191ED1V01Y2009 
04ICR006

Chitraa, V., \& Thanamani, A. S. (2012). An Enhanced Clustering Technique for Web Usage Mining. International Journal of Engineering Research \& Technology (IJERT), 1(4), 1-5.

Coker, B. L. S. (2011). Freedom to surf: The positive effects of workplace Internet leisure browsing. New Technology, Work and Employment, 26(3), 238-247. https://doi.org/10.1111/j.1468-

005X.2011.00272.X

Dong, D. (2009). Exploration on Web Usage Mining and Its Application. Analysis, 1-4. https://doi.org/10.1109/IWISA.2009.5072860

Fathonah, N., \& Hartijasti, Y. (2014). the Influence of Perceived Organizational Injustice Towards Workplace Personal Web Usage and Work Productivity in Indonesia. South East Asian Journal of Management, 8(2), 151-166.

Kerkhofs, J., Vanhoof, K., \& Pannemans, D. (2001). Web usage mining on proxy servers: a case study. Proceedings of Data Mining for Marketing Applications Workshop at ECML/PKDD 2001, September 3-7 2001, Freiburg (Germany).

Kim, S. J., \& Byrne, S. (2011). Conceptualizing personal web usage in work contexts: A preliminary framework. Computers in Human Behavior, 27(6), 2271-2283. https://doi.org/10.1016/j.chb.2011.07.006

Lüderitz, S. (2006). Pre-processing of webserver logs for data mining. Berlin. Diakses dari https://people.cs.kuleuven.be/ bettina.berendt/ teaching/2007w/adb/Lecture/OtherSlides/lued eritz-presentation1-slides_2006_07_10.pdf tanggal 15 September 2016

Nithya, P., \& Sumathi, P. (2012). Novel PreProcessing Technique for Web Log Mining by Removing Global Noise, Cookies and Web Robots. International Journal of Computer Applications, 53(17), 1-6.

Pamutha, T., Chimphlee, S., Kimpan, C., \& Sanguansat, P. (2012). Data Preprocessing on Web Server Log Files for Mining Users Access Patterns. International Journal of Research and Reviews in Wireless Communications (IJRRWC), 2(2), 92-98.

Roiha, N. U. (2017). Segmentasi Pengguna Web Menggunakan Metode Genetic K-Means Algorithm. Tesis. Institut Teknologi Sepuluh November

Weinreich, H., Obendorf, H., \& Herder, E. (2006). Data cleaning methods for client and proxy logs. Workshop on Logging Traces of Web Activity: The Mechanics of Data Collection; 2006 Mei 23; Edinburgh (GB): Dalhousie University.

Xu, J., \& Liu, H. (2010). Web User Clustering Analysis Based on K-means Algorithm. Proceedings of the International Conference on Information Networking and Automation (ICINA),

2 ,

V2-6-V2-9. https://doi.org/10.1109/ICINA.2010.5636772

Yusriani, E., \& K. Suprapto, Y. (2016). Pemodelan Prediksi Pola Akses Website Pemerintah menggunakan Classification via Regression. Jurnal Masyarakat Telematika Dan Informasi, $7(1), 1-12$.

Zhang, Y., Dai, L., \& Zhou, Z.-J. (2010). A New Perspective of Web Usage Mining: Using Enterprise Proxy Log. 2010 International 
Conference on Web Information Systems and

Mining, $38-42$.

https://doi.org/10.1109/WISM.2010.20

Zubi, Z. S., Saleh, M., \& Raiani, E. (2014). Using

Web Logs Dataset via Web Mining for User
Behavior Understanding. International Journal of Computers and Communications, 8 , 103-111. 